\title{
What Sports Advertising Tell to Us? Semiotic Analysis
}

\author{
Velittin Balci ${ }^{1}$, Caner Özgen ${ }^{2}$ \\ ${ }^{1}$ Ankara University, Faculty of Sport Sciences, Ankara, Turkey \\ ${ }^{2}$ Anadolu University, Faculty of Sport Sciences, Eskişehir, Turkey \\ Correspondence: Velittin Balci, Ankara University, Faculty of Sport Sciences, Ankara, Turkey.
}

Received: April 14, 2017

doi:10.11114/jets.v5i6.2387
Accepted: April 17, $2017 \quad$ Online Published: April 24, 2017

URL: https://doi.org/10.11114/jets.v5i6.2387

\begin{abstract}
A very important parts of TV commercials are the messages and how they convinced people. In addition, the information given in commercials may contain messages that seem like a fact however, they may not be true. To understand these commercials it is more beneficial to observe how they say instead of what they say. In many studies (Ferreira, et al. 2006; Muratović, et al., 2014; Pyun, et al., 2012) it is stated that consumers positive attitudes are developed to products which are in the commercial that use sports image. In this context, the purpose of this study is to criticize the TV commercials that's use sports image by using semiotics-analyzing method. Clear Men, Türkiye Finans (Turkish Finance Bank ) and TEB economy commercials that are broadcasted on television channels in Turkey were chosen by using purposive sampling. Selected commercials are analyzed by semiotics-analyzing method. The result of this study indicated that these companies are using sports image effectively in TV commercials with various advertising strategies to achieve their marketing objectives. Using sports image in TV commercials does not only contribute the companies but also contribute sports image and popularity of the athletes. This relationship between sports and commercials has a crucial effect on development of each other. In light of this information, it can be state that researches on sports related commercials are so useful for sports managers and advertisers.
\end{abstract}

Keywords: sports image, advertising, semiotics

\section{Introduction}

The increasingly competitive market environment has led to a tremendous advertising pollution in media tools, which has made it very challenging to come up with ads attractive enough to grab consumers' attention. In various studies, it has been shown that consumers are developing more positive attitudes towards products using sports image than general advertisements (Ferreira, et al., 2006; Muratović, et al., 2014; Pyun, et al., 2012). This demonstrates how important sports are for advertisers and businesses. All these developments have resulted in a growing academic interest in advertising through sports (Balc1 \& Sunay, 2003; Bush, et al., 1999; Ferreira, et al., 2006; Muratović, et al., 2014; Harshaw \& Turner, 1999; Yıldız, et al., 2007).

The reason why sport commercials are so effective is that star players take a part in these commercials. Bowman (2002), stated that the commercials which have star players in it are more effective on giving marketing massages. According the this fact most of companies use star player in their commercials. Therefore sport commercials have become on of the major elements of commercials endüstry (Kambitsis et al., 2002).

A very important part of any television commercial is the message, and while some things are told about a product, the goal is to persuade the consumer to purchase it. While such information provided about a product in an advertisement can be accurate, it may also contain messages that are inaccurate or exaggerated in an attempt to convince consumers to buy the product. Therefore, ignoring the structural content of the advertisements by the viewers leads to a lack of comprehension by the society that advertisements are the invisible carriers of certain messages. Thus, Williamson (2001) asserts that what advertisements mean can only be grasped by comprehending how they mean what they say and deciphering how they are constructed. It is observed that many studies in the advertisement literature (Anderson, et al., 2006; Aydın \& Aslaner, 2015; Becan, 2012; Domzal \& Kernan, 1992; Freire, 2014; Horzum, 2011; Lee, 2015; Yakın, et al., 2014) use the semiotic method of analysis to figure out these hidden meanings. However, when the related literature is analyzed, no studies to date could be found that specifically analyzes how sports image is used in advertising through semiotic analysis, with all its dimensions and in a detailed way. In the light of this information, by using the semiotic 
analysis method, this study is designed to reveal how some commercials aired on Turkish TV channels use the sports image. To achieve this study aim, a comprehensive review of literature has been conducted on the sports-advertising relationship, and three commercials (Clear, Türkiye Finans, TEB Ekonomi) determined through judgement sampling have been analyzed through semiotic analysis method. Finally, the research findings are discussed in the light of the relevant literature. The study is significant because by being one of the very few studies in the field, it fills an important gap by providing an in-depth discussion of the reasons for using the sports image in advertising.

\section{Method}

By employing semiotic analysis, this study was designed to reveal the meanings of the advertisements with sports image. Semiotic analyses are commonly used in advertising research to unearth the embedded meanings in advertisements (Anderson, et al., 2006; Aydın \& Aslaner, 2015; Domzal \& Kernan, 1992; Freire, 2014; Lee, 2015; Yakın, et al.,2014). The review of the relevant semiotic analysis research literature reveals that the judgement sampling method is widely applied in this field of research (Aydın \& Aslaner, 2015; Yüksel, 2015). In the judgmental sampling methodology, the aim is to create a targeted sample to fit the specific research purpose on the basis of researcher's judgements, and his/her previous experiences (Monette et al., 1990). As such, three commercials (Clear Men, Türkiye Finans, and Ekonomi) were selected for analysis by using the judgement sampling in line with the aim of the study. The research data were analyzed by two researchers separately. As a result of this, our research has found similar results. This is evidence of the validity and reliability of the research (Kassarjian, H.H.,1977).

\section{Semiotic Analysis}

It is difficult to do a holistic analysis of an advertisement without evaluating the denotative (plain) and connotative (side) meanings of the signs shown in them. Semiotics is a branch of science that studies signs, and researches how people create signs, build a system from those signs, and communicate through this channel. Semiotics emerged as an alternative to the concept of seeing communication as a process. Contrary to this understanding, communication is a field of meaning production (Güngör, 2013). The most effective method in decoding advertisements is the semiotic analysis (Williamson, 2001). Semiotic analysis, which is frequently used in media studies, is quite different from content analysis which is the most widely used method in this sense. Semiotic analysis focuses on the system of principles which dominate the discourse of these texts, while the main focus in content analysis is the number and the frequency of word groups in a text. Therefore, while the content analysis method is a quantitative approach, the semiotics analysis opposes this type of work (Parsa \& Parsa, 2012; Yakın, et al., 2014).

Table 1. Semiotic System Table

\begin{tabular}{ll}
\hline Sign & Commercial Film \\
\hline Signified & $\begin{array}{l}\text { Visual text (all visual elements in the commercial film and their presentation style), } \\
\text { verbal text (external sound, slogan, speech, music and sound effects), written text } \\
\text { (slogan, logo) }\end{array}$
\end{tabular}

Signifier

Analysis
The connotations that took part beside signified in the commercial movie.

Assessment of the relationship between the signified and signifier.

Martin, B. (2006). Key terms in semiotics. New York: Continuum Books.

\subsection{Clear Men Advertisement}

In this commercial film main character is famous football player Ronaldo while signified product is Clear Men brand, the signified is the Clear Men brand. The signifier is the world-famous footballer Cristiano Ronaldo and a group of children playing football. The commercial shows the story of Ronaldo's retrieving a running football of some kids playing in an urban area from some dangerous places of the inner city with his agility and superior football skills. At the end of the film, Ronaldo proudly shows off his still dandruff-free and smoothly kempt hair. In the commercial film signifies a handsome, strong and popular football player.

In the first scene of the commercial film, Cristiano Ronaldo, who is world-famous for his football talent and good physique, is seen walking in the downtown area of a city which is obviously big and crowded. In the second scene, the ball of a group of children who are seen playing football in the city center runs to the middle of a street, and Ronaldo, who sees it, takes action with a sarcastic smile on his face. The most important thing shown here is that it will not be hard to save a ball for a strong, popular and good athlete. In the next scene, the children are surprised to see a superhero when they see Ronaldo. In the ensuing scene, Ronaldo follows the ball with the power and flexibility of a superhero, passing through impossible places. The strong, healthy representation of the body of a sportsman is placed in the center of the film. 
In the following scene, it is shown with visual scenes supported by an external sound that the dirty air of urban life causes dandruff to form in the hair of modern man who has to be constantly out and how it can be washed away with Clear brand shampoo. The next scene shows Ronaldo's retrieval of a football with an aesthetic football move, followed by Ronaldo's warm interest in the boys whose ball he has just brought back. Ronaldo, a strong and popular athlete, is attributed superhero strength in this commercial. It is emphasized that a strong athlete, such as the one shown here, is able to easily perform a number of movements that ordinary people cannot do, highlighting the health and fitness dimension of sports. In this commercial, the target population is obvious: the modern humans inhabiting the crowded city centers. Throughout the commercial film, what is signified is quite clear: one of the greatest passions of modern human is football, and clear references throughout the advertisement to the brand through a powerful and popular football player at the summit of modern football.
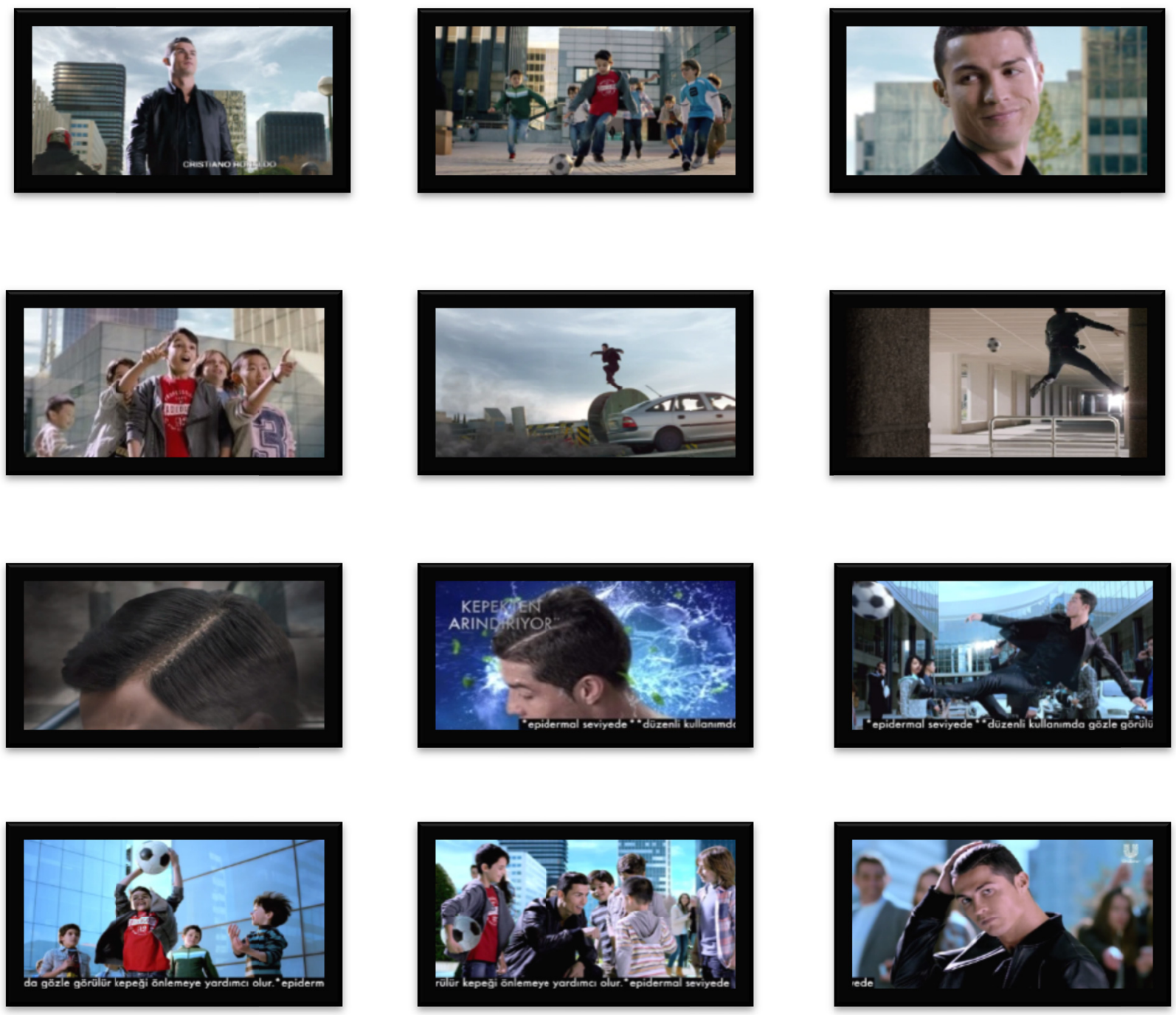

Figure 1. Clear Men Advertisement Images

Celebrity use in advertisements is a popular advertising practice that businesses constantly use to support their corporate and brand image (Erdogan, 1999). Today's modern consumers are bombarded with advertising messages both in and outside the public arena, which reduces the effectiveness of advertisements and the recall of messages. The use of celebrity in advertising is also very influential on remembering the advertising messages sent, as well as positively contributing to the brand's image and reputation (Bowman, 2002; Shimp, 2003). Kambitsis et al. (2002) state that the use of sports celebrity in advertisements makes a significant contribution to the corporate and brand image of advertisers. Especially if we think in terms of brand-image fusion, Ronaldo is a sufficient signifier alone as a strong character in the commercial. In the purchasing behavior of consumers the brand of products that will give them prestige or status is an important determinant. Consumers identify themselves with the prestige set forth in their product 
advertisements by purchasing the related products and express themselves in this status to other individuals. Thus, by running a commercial campaign with a famous sportsman, Clear has been making a significant contribution to its brand image, recognition and sales.

In addition to all these, using children fans rather than adult fans (customers) in the images will make it easier for the viewers to establish the relationships implied by the advertisement. The relationship between children's interest in hair care and their Ronaldo admiration or strong image appears not to be a close one from the semiotic perspective.

\subsection{Turkish Finance Bank Advertisement}

In the commercial film in which another celebrity football player is the main character, the signed is Türkiye Finans bank. The signifiers are the famous footballer Arda Turan and a bank employee. The famous footballer Arda Turan comes to a bank and says that he wants to apply for sponsor (financial provider). The bank employee is gets quite surprised, and so Arda tells him why he needs a sponsor, and filing his application, Arda leaves the bank happily.

What is shown in this commercial is a popular and rich football player. In the first scene of the commercial, the celebrity footballer Arda Turan gets a customer queue number in a bank and his number in the queue is 10, which signifies Arda's foorball team jersey number that he always wears. What is signified here is that even if you are a celebrity, in this bank you have to get in the queue, and you get equal service no matter who you are, by referencing to the real life character of the player. In the next scene, the bank employee is very excited to see Arda, and he begins to scream with joy. Here we see strong references to the popularity of the celebrity sportsman, that is the football player is such a popular one that everybody seeing him gets excited. In the following scene, Arda says that he wants to apply for a sponsor and the bank worker thinks that Arda is joking. What is shown here is that even a bank employee will not buy into the idea that such a popular and rich sportsman would need to make a sponsor application.

In the next scene, in order to explain why he needs to make the sponsorship application, Arda draws an imagination bubble in the air with his finger. In the imagination bubble that just pops up, Arda says that he may have a serious injury, he may lose all his wealth and popularity, and his life may suddenly change its course for the worse. What is demonstrated in this scene is that however famous and powerful we might be, we always run the risk of suffering an unexpected accident, and we need to take measures for such incidents. So, upon this explanation, there is no trace left of the excitement and perplexion of the employee. The scene ends with the employee completing Arda's application.

What is signified here is, it is normal that even such popular and rich people need to take some financial precautions. In the next scene, on his way out of the bank after completing the application procedures and putting the card in his pocket, Arda says "Well! I am now relieved" and leaves the bank contentedly. In this scene, the reference is made to how relieving it is to take such financial measures as shown in the ad. Based on the popularity of sports and the wealth of sportsmen throughout the commercial, the viewers are ensured to make the association that such people's worries about their future are related to their financial investments. Simply put, this can be said to be an effective commercial regarding the sign, the signifier, and the signified.

The identification of a certain brand with a famous person who has previously been a star will enable the brand to become a star itself in a very short time (Tek, 1999). This strategy has often been used recently in advertisements for products that are difficult for people to decide, like banking (Odeobank Hülya Avşar- Akbank Kıvanç Tatlituğ ve İlker Ayrık, TEB,Olgun Şimşek, İşbank Maximum kart Tolga Çevik, Garanti Bonus Gülse Birsel, Denizbank Beyazıt Öztürk ve Erdal Özyağcılar, İşbankası Cem Yılmaz ve Mehmet Ali Alabora, ING Bank Acun Ilıcalı, Halk Bankası Paraf card Murat Boz, Finansbank Şafak Sezer, Mustafa Keser). Sports celebrities also acted in bank advertisements (ING Bank-Frank de Boer, Garanti Bank- Roberto Carlos). We see the same aim in this commercial, where Arda Turan is the main character actor. Celebrities in our life as role models affect not only the things we eat, drink, wear, but also influence our bank choices. The use of celebrity sportsmen as a marketing tool makes them more popular as well. With the commercials he appears, alongside his athlete identity, Arda has made an important contribution to his popularity, as is the case for other comparable sports celebrities of the world (Beckham, Ronaldo, etc.). 

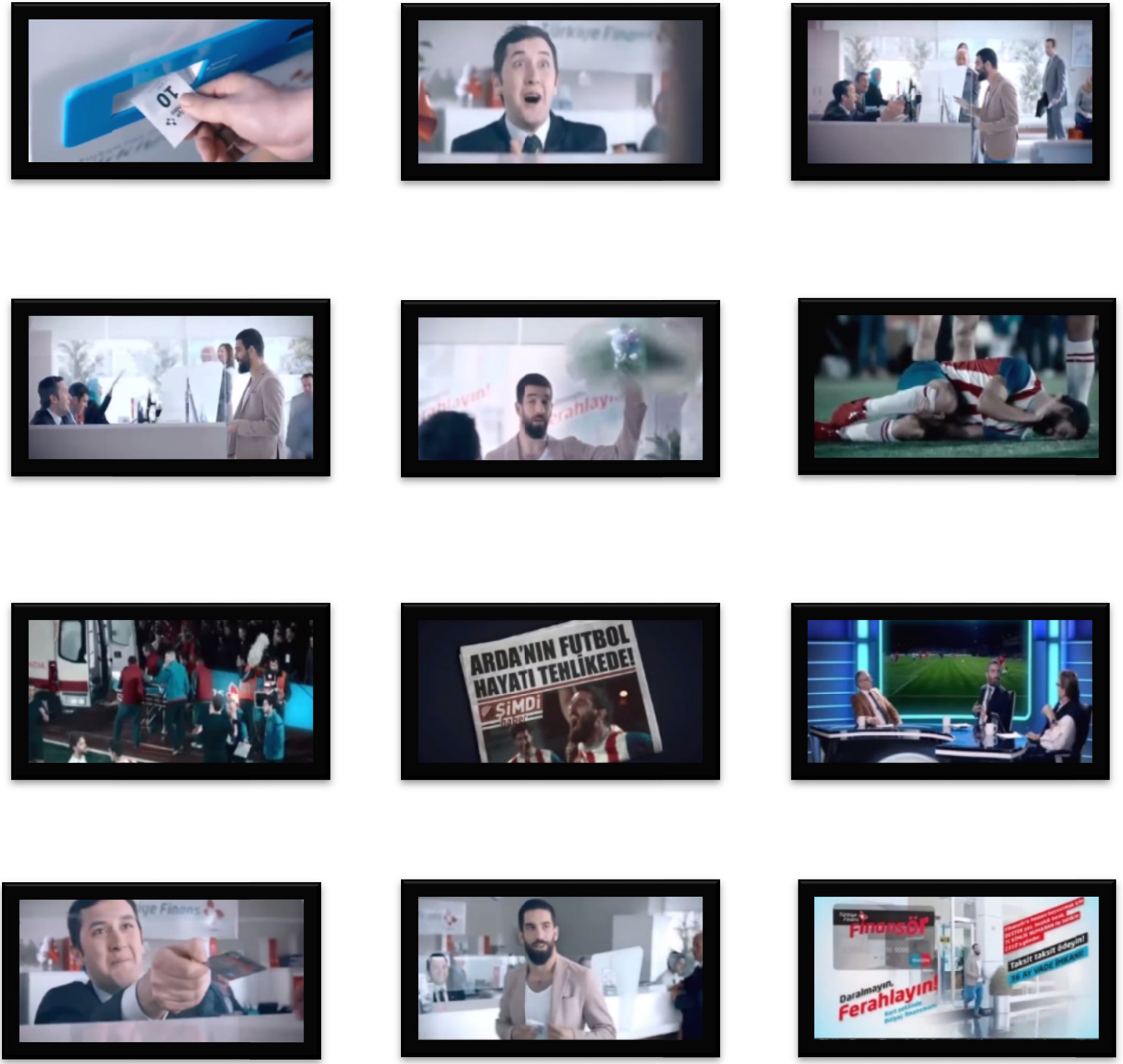

Figure 2. Turkish Finance Advertising Images

However, despite the fact that the use of celebrities in advertisements has a significant contribution to the corporate and brand image, this situation poses various risks. In particular, the most important of these risks are that the celebrity person may overwhelm the advertised brand and the message in the advertisement, the celebrities included in the advertisement campaign may get involved in an incident resulting in negative publicity, and the image of the celebrity in the advertisement may not overlap with the product advertised (Şimşek \& Uğur, 2003). As it is the case for all sportsmen, Arda's public image follows a trend of sudden changes. It is possible that this ad may have a negative impact on the target audience during or after an important football match where Arda plays particularly badly. However, despite being a global player, Arda is a player who is associated with a prominent team (Galatasaray) on the national level. This situation may cause a negative perception of the bank by the supporters of other teams nationwide.

\subsection{Turkish Finance Bank Advertisement}

It can be said that this commercial film, designed on behalf of TEB, "hunts multiple birds with one stone". This is because, the signifier in this commercial successfully uses the elements of a popular sports branch as well as the elements of a popular music genre.

These two components are shown in the opening scene of this commercial film. In this commercial, the signifier consists of a popular sports branch (tennis) and various people involved in this sport (tennis fans, tennis athletes), and also a popular music genre (rap) and artist. Looking at the film content, we see that a well-known rap artist sings a song 
with lyrics about tennis loyalty (supporting tennis), and then influencing the masses by expressing physical, social and emotional associations invoked by tennis such as gentility, motivation, agility, coordination, focus on work and enthusiasm in tennis, ending with the introduction of the product with the introduction of the bank.

It can be said that, with this content the advertisement contains important arguments to raise interest in the tennis sport. The visuals give the impression that it is a successful advertising design in that they show the bank in the background as supporting this sport as well as the elements that introduce the tennis sport. One of the important economic characteristics of the sport is that it is a joint product (Pedersen et al., 2007).

The bank does not aim to promote any of its products or services with this advertisement. The aim here is to make a sales promotion by using the cause-related marketing strategy. By utilizing the social image and popularity of sports, TEB Economy Bank aimed to make its products and services more appealing to the target group (Odabaş1 \& Oyman, 2002). From this point of view, it will be more accurate to tactically and strategically evaluate the messages given in the commercial film. The establishment of an academy with tennis players and volunteers who are interested in tennis and the conversion of these people into bank customers in the content of the advertisement can be seen as a tactical goal. However, when the subject is evaluated within the scope of strategic targets, it is considered that such activities will make significant contributions to the brand image in the long term. Such activities can help create critical differences in the establishment of emotional connections with the target audience concerned, the removal of various consumer suspicions, and the enhancement of brand recognition.
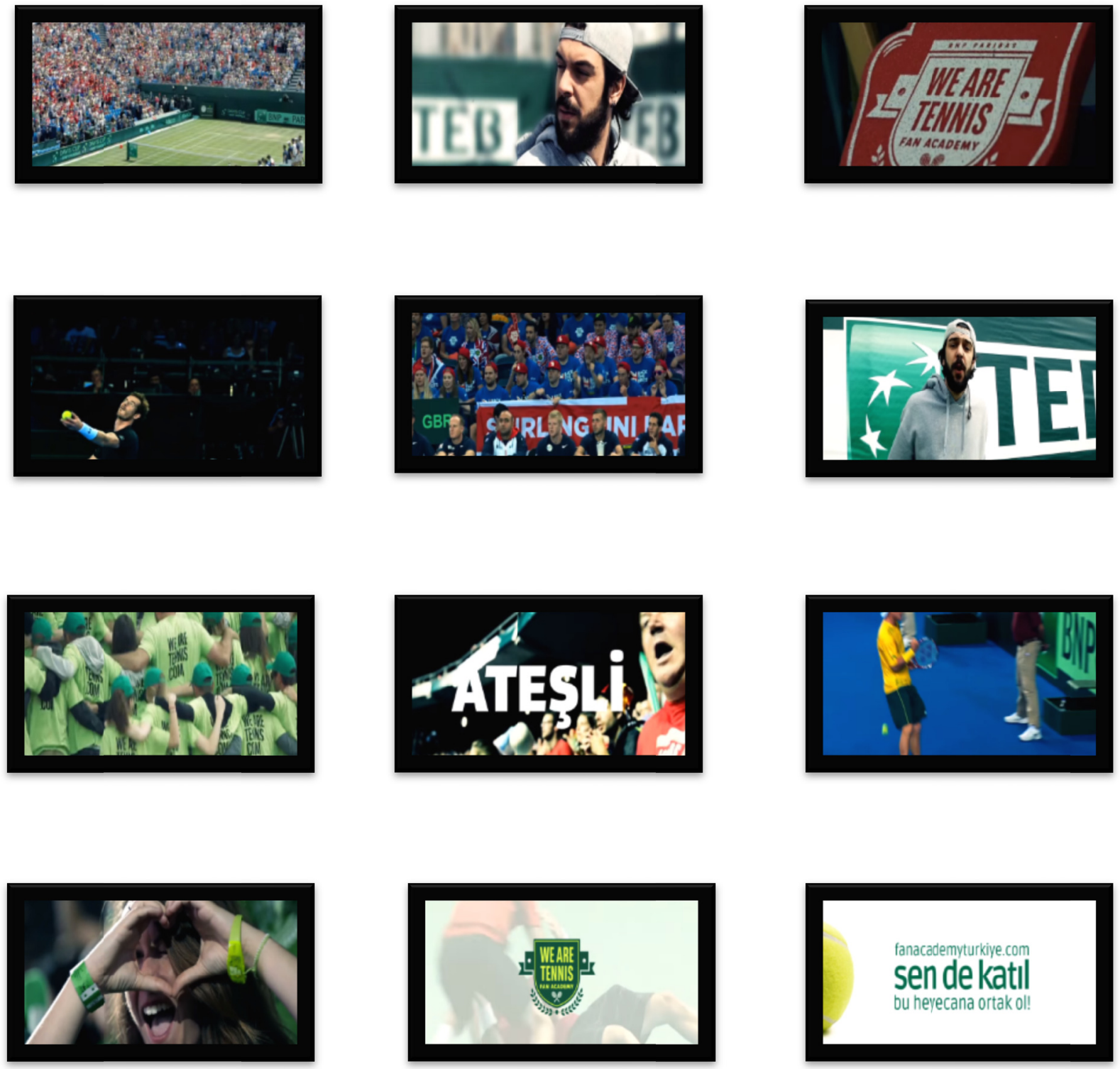

Figure 3. TEB Economy Bank Images 


\section{Discussion}

Albert Lasker, known as the founder of modern advertising, defined the ad as "salesmanship in print". But this definition is inadequate in today's modern world of diverse and powerful communication channels. Because of the developments in technology, population, media and brand structure, today's advertising requires a much more different and challenging process than in the period it appeared first. Especially in developing societies, advertising is the most effective method of communicating with the target audience, products and brands (Altunbaş, 2008). The emergence of new advertising techniques every day and the use of these advertising techniques in public and private areas cause the individual to be exposed to constantly increasing commercial bombardments throughout the day. Research has shown that individuals' attitudes towards TV commercials are more negative than they are towards general advertisements (Mittal, 1994), and they have more negative attitudes against spam, mails, and pop-ups than TV commercials (Burns, 2003). As a result of all this, people are trying to avoid this advertising bombardment, which is pushing advertisers to look for new advertising platforms. Sports is one of the most important emotions that consumers have created from these platforms.

The aim of modern marketing approaches is not only to satisfy the needs of the consumer, but also to create new needs for them. The most important tool for creating these new needs is advertising. Effective advertising should definitely be based on the lifestyles of the people in the target audience. Pedersen, et al., (2007) state that advertising strategies that incorporate sports images are very important tools in creating awareness and influencing consumption behavior due to the nature of sports. This common purpose is evident in all of the commercials analyzed within the scope of the present study.

The selection and development of the content of advertising messages has a great impact on the purchasing decisions of consumers in the target audience. In the creation of advertising messages, it is necessary to determine in advance what the message will say, how to say it and how to structure it (Odabaş1 \& Oyman, 2005). For this purpose, advertisers spend a lot of time to send messages that can convince the target audience. These messages, based on the characteristics of the audience, can be informational or emotional (Jang et al., 2014). It is seen that in the commercial films subject to this research, the power of sports' popularity in influencing large masses is utilized. In particular, the aim is to influence consumers' purchasing behavior by combining the positive image provided by sports with the product. Regarding the commercial film roles played by prestigious athletes, the aim is to add value to the product through this prestige and to market these values to consumers.

Sports is an important element in which cause-related marketing strategies aimed at sales promotion can be used. This strategy appears to have been used in the commercials analyzed. In addition to this, the use of sports images by businesses and advertisers in advertisements makes a significant contribution to the development of sports and the popularity of the athletes, as well as contributing to the promotion of the advertised product. Regarding the subject, Balc1 \& Sunay (2003) point out that the use of sports image provides mutual benefit between advertisements and sports elements in advertising which is one of the most important vehicles in product promotion and sales. While companies achieve their sales objectives by making effective and persuasive advertising campaigns thanks to sports image, it also increases the popularity of the sports and contributes significantly to educating the community through sports.

When the studies on the use of sports image in advertisements are examined, it can be said that the results obtained from our research are similar to those reported in the relevant literature. Today, advertising channels have been diversified and thanks to this diversity the difficulty of reaching consumers has been eliminated, but at the same time it has become difficult to send messages to attract consumers. The increasing cost and questionable effectiveness of traditional advertising has made it compulsory to find new advertising platforms and techniques. One of the most important of these platforms is the sports, and the sports image continues to be used effectively due to the success it has achieved in advertising.

\section{Limitations and Future Research}

In this study, three advertisements (TV commercials) determined by judgement sampling method were examined through semiotic analysis. However, the study has revealed the necessity of analyzing more advertisements. Furthermore, analysis of films that contain sports images in addition to television ads may allow different results to be obtained. This study focuses only on commercial films broadcast on Turkish television. Therefore, conducting research that will reveal how the sports image is used in commercial films broadcast at the international level may also introduce new perspectives on the subject.

\section{References}

Altunbaş, H. (2008). Sport Marketing and Communication. Konya: Tablet Publications.

Anderson, S. J., Dewhirst, T., \& Ling, P. M. (2006). Every document and picture tells a story: using internal corporate document reviews, semiotics, and content analysis to assess tobacco advertising. Tobacco control, 15(3), 254-261. 
https://doi.org/10.1136/tc.2005.013854

Aydın, G., \& Aslaner, D. A. (2015). Presentation of Stereotip Women's Roles in Television Advertisements. Global Media Journal: Turkish Edition, 6(11).

Balc1, V., \& Sunay, H. (2003). Use of the Sport Image in the Advertisements Published by Some Turkish Televisions. Sportsmeter, 107-110.

Becan, C. (2012). Reading "Indicators" in the Context of New (Affective) Advertisement Transmission: An Advertisement Message Analysis Using the Semiological Method. Yalova University Journal of Social Sciences, 2(4).

Bowman, J. (2002). Facing Advertising Reality. Media Asia, 7(26), 14-15.

Burns, K. S. (2003). Attitude toward the online advertising format: A reexamination of theattitude toward the ad model in an online advertising context. Unpublished doctoral dissertation, University of Florida, Gainesville.

Bush, A. J., Smith, R., \& Martin, C. (1999). The influence of consumer socialization variables on attitude toward advertising: A comparison of African-Americans and Caucasians. Journal of Advertising, 28(3), 13-24. https://doi.org/10.1080/00913367.1999.10673586

Domzal, T. J., \& Kernan, J. B. (1992). Reading advertising: The what and how of product meaning. Journal of Consumer Marketing, 9(3), 48-64. https://doi.org/10.1108/07363769210035233

Erdogan, B. Z. (1999). Celebrity endorsement: A literature review. Journal of marketing management, 15(4), 291-314. https://doi.org/10.1362/026725799784870379

Ferreira, M., Siders, R., Tsuji, Y., \& Cianfrone, B. (2006). Analysing the effects of advertising type and antecedents on attitude toward sadvertising in sport. International Journal of Sports Marketing \& Sponsorship, 62-81.

Freire, N. A. (2014). When Luxury Advertising Adds the Identitary Values of Luxury: A semiotic Analysis. Journal of Business Research, 67(12), 2666-2675. https://doi.org/10.1016/j.jbusres.2014.04.004

Güngör, N. (2013). Communication Theories and Approaches. Ankara: Political Bookstore.

Harshaw, C. E., \& Turner, E. T. (1999). Assessing the Recognition of Perimeter Advertising Signage by Television Viewers of NASCAR Winston Cup Events. Sport Marketing Quarterly, 8(4), 7-35.

Horzum, I. (2011). The Semiotic Analysis of Modern Myths and The Green Myth in Advertisements. Humanities Sciences, 6(1), 29-41.

Jang, W., Ko, Y. J., \& Stepchenkova, S. (2014). The Effects of Message Appeal on Consumer Attitude Toward Sporting Events. International Journal of Sport Communication, 7(3), 337-356. https://doi.org/10.1123/IJSC.2014-0003

Kambitsis, C., Harahousou, Y., Theodorakis, N., \& Chatzibeis, G. (2002). Sports Advertising in Print Media: The Case of 2000 Olympic Games. Corporate Communications: An International Journal, 7(3), 155-161. https://doi.org/10.1108/13563280210436763

Kassarjian, H. H. (1977). Content Analysis in Consumer Research. Journal of Consumer Research, 4, 8-18. https://doi.org/10.1086/208674

Lee, S. J. (2015). Unraveling the" model minority" stereotype: Listening to Asian American youth. Teachers College Press.

Ling, K. C., Piew, T. H., \& Chai, L. T. (2010). The determinants of consumers' attitude towards advertising. Canadian social science, 6(4), 114-126.

Martin, B. (2006). Key terms in semiotics. New York: Continuum Books.

Mittal, B. (1994). Public Assessment of Tv Advertising: Faint Praise And Harsh Criticism. Journal of Advertising Research, 34(1).

Monette, D. R., Sullivan, T. J., \& De Jong, C. R. (1990). Applied Social Research: Tool for the Human Services. 2nd ed. London: Harcout Brace Jovanovich College Publishers.

Muratović, A., Bjelica, D., \& Popović, S. (2014). Examining Belifs and Attitudes Toward. Examining Belifs and Attitudes Toward, 12(2), 95-104.

Near, V., Moon, C., \& Near, M. (2014). Semiological Analysis of Brand Personality Archetypes Used in Advertisements. Management and Economics, 21(1), 345-355.

Odabaşı, Y., \& Oyman, M. (2002). Marketing Communication Management, 11th Edition, MediaCat Books. 
Parsa, S., \& Parsa, A. F. (2012). Semiotics Analysis. Izmir: Ege University Publications

Pedersen, P., Miloch, K., \& Laucella, P. (2007). Strategic Sport Communication. Leeds: Human Kinetics.

Pyun, D. Y., \& James, J. (2010). Attitude Toward Advertising Through Sport: A Theoretical Framework. Sport Management Review, 14(1), 33-41. https://doi.org/10.1016/j.smr.2009.12.002

Shimp, T. (2003). Advertising and Promotion: Supplemental Aspects of Integrated Marketing Communications. (6th ed.). New York: Dryden Press.

Şimşek, S., \& Uğur, İ. (2003). Star strategy and applications. Selcuk University Journal of Social Sciences Institute, 10, 349-358.

Single, Ö. B. (1999). Marketing principles Global management approach Turkey applications. Beta Publications, Istanbul, 196-226.

Williamson, J. (2001). The language of the ads. (A. Fethi, Çev.) Ankara: Utopia Publications.

Yildiz, Y., Çetinöz, F., Kaplan, Y., \& Turkmen, M. (2007). The Use of Sports Image in TV Advertisements and the Impact on Consumer Behavior. Journal of Sport Management and Information Technologies, 2(1), 5-13.

Yüksel, N. A. A. (2015). Representations of School, Teacher and Student in Cinema Films in Turkey as a Cultural Product. Global Media Journal: Turkish Edition, 6(11).

\section{Copyrights}

Copyright for this article is retained by the author(s), with first publication rights granted to the journal.

This is an open-access article distributed under the terms and conditions of the Creative Commons Attribution license which permits unrestricted use, distribution, and reproduction in any medium, provided the original work is properly cited. 